\title{
PENGARUH PENGGUNAAN BERBAGAI VARIASI KOMPOSISI TEPUNG DAN JENIS SUSU TERHADAP MUTU KERUPUK SUSU
}

\section{THE EFFECT OF USING VARIOUS VARIATION OF FLOUR COMPOSISTION AND MILK TYPE TO THE QUALITY OF MILK CRACKERS}

\author{
Agusri Ramadhan ${ }^{1)}$, Ekwan Sabar Rantas ${ }^{2)}$ \\ 1) Dinas Ketahanan Pangan, Provinsi Bengkulu \\ 2) Program Studi Teknologi Pertanian, Fakultas Pertanian, Universitas Dehasen Bengkulu \\ Email :r.agusri@gmail.com
}

\begin{abstract}
ABSTRAK
Penelitian ini bertujuan untuk mengetahui pengaruh penggunaan berbagai variasi komposisi tepung (terigu, beras, dan tapioka) dan jenis susu terhadap mutu kerupuk susu yang dihasilkan. Penelitian ini menggunakan Rancangan Acak Lengkap (RAL) dengan menggunakan dua faktor beda, yaitu komposisi tepung (terigu, beras dan tapioka) yang terdiri dari 4 taraf (100 g : $150 \mathrm{~g}: 250 \mathrm{~g}, 150 \mathrm{~g}: 250 \mathrm{~g}: 100 \mathrm{~g}$, dan $250 \mathrm{~g}: 100 \mathrm{~g}: 150 \mathrm{~g})$ dan jenis susu yang terdiri dari 2 taraf (susu kedelai dan susu sapi). Variable yang diamati meliputi kadar protein, kemekaran, tekstur, dan organoleptik meliputi warna, aroma, rasa dan tekstur. Hasil penelitian menunjukkan bahwa penggunan berbagai variasi komposisi tepung dan jenis susu tidak memberikan pengaruh yang signifikan terhadap kadar protein kerupuk susu tetapi berpengaruh terhadap tingkat kerenyahan, kemekaran, dan sifat organoleptik kerupuk susu yang dihasilkan.
\end{abstract}

Kata kunci : Kerupuk Susu, Susu Kedelai, Susu Sapi, Tepung

\begin{abstract}
The aim of this research is to determine the effect of using various variation of flour composition and milk to the quality of milk crackers. This study used completely randomized design (CRD) using two different factors: composition of flour (wheat, rice, and tapioca) with four level $(100 \mathrm{~g}: 150 \mathrm{~g}: 250 \mathrm{~g}, 150 \mathrm{~g}: 250 \mathrm{~g}: 100 \mathrm{~g}$ and $250 \mathrm{~g}: 100 \mathrm{~g}: 150 \mathrm{~g}$ ) and type of milk with two level (soy milk and milk). Observed variables consist of protein content, level of crispness, efflorescence, and organoleptic characteristics including color, flavor, taste and texture. The results showed that the use of variation composition of flour and milk type didn't have a significant effect on protein content of milk crackers, but affect the level of crispness, efflorescence, and organoleptic characteristics of milk crackers.
\end{abstract}

Keywords: Milk Crackers, Soy Milk, Milk, Flour 


\section{PENDAHULUAN}

Kerupuk adalah makanan kecil yang bersifat kering, ringan, dan porous yang terbuat dari bahan-bahan yang mengandung pati cukup tinggi. Produk ini merupakan makanan khas yang digemari masyarakat (Wiriano, 1984). Berdasarkan Standar Nasional Indonesia tahun 1992, kerupuk adalah suatu produk makanan kering yang dibuat dari tepung pati dengan penambahan bahan - bahan lainnya dan bahan tambahan makanan yang diijinkan. Berdasarkan bentuk dan rupanya, maka dikenal pula jenis kerupuk mie, kerupuk kemplang, dan kerupuk atom. Mutu kerupuk dapat dinilai dengan menggunakan beberapa parameter, yaitu bersifat sensori, kimiawi, fisik, maupun mikrobiologis. Bahan baku yang paling banyak digunakan untuk pembuatan kerupuk adalah tepung tapioka. Namun banyak juga yang menggunakan bahan dasar tepung terigu, tepung beras, tepung jagung, tepung kacang hijau, tepung kedelai dan tepung sagu (Wiriano 1984).

Komponen terbesar kerupuk adalah pati sehingga kerupuk mempunyai kandungan protein yang rendah. Perlu dilakukan usaha penganekaragaman makanan (diversifikasi pangan) yang bertujuan meningkatkan kandungan gizi kerupuk terutama kandungan protein dan $\mathrm{Fe}$, mengingat kedua zat tersebut sangat dibutuhkan oleh tubuh. Protein sangat dibutuhkan oleh tubuh berkaitan dengan fungsinya sebagai zat pembangun dan $\mathrm{Fe}$ sangat diperlukan untuk pembentukan selsel darah merah sehingga tubuh terhindar dari penyakit anemia (Anggoro, 2007). Pembuatan kerupuk sumber protein dapat dilakukan dengan menambahkan susu kedelai dalam proses pembuatan kerupuk. Susu kedelai merupakan salah satu jenis susu yang tinggi kandungan proteinnya. Kandungan protein pada susu kedelai sekitar 2,7\% (Anggoro, 2007). Penggunaan susu kedelai sebagai bahan tambahan pada pembuatan kerupuk diharapkan dapat meningkatkan kandungan nutrisi yang berimbas pada peningkatan nilai ekonomi produk kerupuk.

Selain susu kedelai, susu sapi juga dapat digunakan sebagai bahan tambahan dalam pembuatan kerupuk susu karena susu sapi mempunyai nilai gizi yang tinggi dan mengandung unsur-unsur kimia yang dibutuhkan oleh tubuh seperti Calsium, Phosphor, Vitamin A, Vitamin B dan Riboflavin yang tinggi. Komposisinya yang mudah dicerna dengan kandungan protein, mineral dan vitamin yang tinggi.

Dalam proses pengolahan kerupuk dari beberapa jenis tepung dengan penambahan susu kedelai diharapkan akan meningkatkan mutu kerupuk susu yang dihasilkan. Untuk itu, perlu dianalisis jenis tepung yang tepat untuk 
menghasilkan kerupuk susu yang berkualitas baik ditinjau dari uji kimia, fisik dan organoleptik.

Penelitian ini bertujuan untuk mengetahui pengaruh penggunaan berbagai variasi komposisi tepung (terigu, beras, dan tapioka) dan jenis susu terhadap mutu kerupuk susu yang dihasilkan.

\section{METODE PENELITIAN}

\section{Alat dan Bahan}

Alat yang digunakan dalam penelitian ini adalah panci, timbangan, kompor, loyang, pisau, talenan, tampah, baskom, sendok, wajan, penetrometer, jangka sorong. Bahan yang digunakan dalam penelitian ini adalah susu sapi, susu kedelai, tepung tapioka, tepung beras, tepung terigu dan tepung campuran, bahan pendukung seperti soda kue, minyak goreng, garam, bawang putih.

\section{Rancangan Penelitian}

Penelitian ini menggunakan Rancangan Acak Lengkap (RAL) dengan menggunakan dua faktor beda yaitu komposisi tepung (terigu:beras:tapioka) yang terdiri dari 4 taraf yaitu $100 \mathrm{~g}: 150 \mathrm{~g}$ : $250 \mathrm{~g}, 150 \mathrm{~g}: 250 \mathrm{~g}: 100 \mathrm{~g}$, dan $250 \mathrm{~g}$ : $100 \mathrm{~g}: 150 \mathrm{~g}$ dan jenis susu yang terdiri dari 2 taraf yaitu susu kedelai dan susu sapi.
Variabel yang diamati dalam penelitian ini adalah kadar protein, kemekaran, tekstur, dan uji organoleptik (warna, rasa, aroma, tekstur).

\section{Tahapan Penelitian}

Pembuatan Kerupuk Susu dengan Berbagai Variasi Komposisi Tepung dan Jenis Susu

Masing-masing sebanyak $500 \mathrm{ml}$ susu kedelai dan susu sapi dipanaskan pada suhu $90{ }^{\circ} \mathrm{C}$. Sebanyak 500 gram campuran tepung terigu, beras, dan tapioka (sesuai perlakuan), 1,5 gram soda kue, 6 gram garam, 6 gram bawang puth ditimbang. Semua bahan dicampur kemudian diadon hingga kalis. Adonan dimasukkan ke dalam plastik dan dikukus selama 1 jam. Dinginkan adonan yang telah dikukus pada suhu ruang selama 1 jam, dilanjutkan didinginkan dalam refrigerator selama 18 jam. Iris-iris dengan ketebalan 2-3 mm. Jemur irisan kerupuk di bawah sinar matahari selama 1-2 hari. Goreng kerupuk dalam minyak panas selama 15-30 detik. Tiris dan dinginkan.

Pengujian Mutu Kerupuk Susu dengan Berbagai Variasi Komposisi Tepung dan Jenis Susu

Kadar Protein

1) Tahap destruksi 
Ditimbang sebanyak 2 gram sampel dan dimasukkan ke dalam labu kjeldhal. Ke dalam labu kjeldhal ditambahkan 2 butir tablet katalis, 5 butir batu didih, dan $15 \mathrm{ml} \mathrm{H} 2 \mathrm{SO} 4$ pekat serta $3 \mathrm{ml} \mathrm{H}_{2} \mathrm{O}_{2} 30 \%$. Labu kjeldhal yang berisi larutan sampel dipanasskan pada alat destruksi dalam lemari asam dengan suhu $450{ }^{\circ} \mathrm{C}$ selama 2 jam (sampai contoh jernih).

2) Tahap destilasi

Sebanyak $100 \mathrm{ml}$ aquades ditambahkan ke dalam labu hasil destruksi kemudian labu tersebut dimasukkan ke dalam alat destilasi uap. Diambil sebanyak $25 \mathrm{ml} \mathrm{H} 3 \mathrm{BO} 4$ dan dimassukkan ke dalam erlenmayer $250 \mathrm{ml}$. Kemudian ditambahkan 2 tetes indikator methyl red lalu alat destilasi dipasangkan.

3) Tahap titrasi

Destilat dari hasil destilasi selanjutnya dititrasi dengan larutan standar $\mathrm{HCl}$ 0,2 $\mathrm{N}$ hingga titik akhir titrasi yang ditandai dengan perubahan warna dari kuning menjadi merah muda (pink). Perhitungan kadar protein (\%) dapat dilakukan dnegan menggunakan rumus sebagaii berikut :

Kadar Protein $(\%)=$ (S-B)L x N HCl x 14, $008 \times 5,71$ W $\times 100$

Keterangan :

$\mathrm{W}=$ berat sampel (gram)
$\mathrm{S}=$ jumlah titrasi sampel (ml)

$\mathrm{B}=$ jumlah titrasi blanko $(\mathrm{ml})$

$\mathrm{V}=$ volume $\mathrm{HCl}$ standar dalam titrasi

$14,008=$ berat atom Nitrogen

5,71 = faktor konfersi protein kedelai

\section{Kemekaran}

Kemekaran kerupuk susu ditetapkan dengan melihat perubahan luasan kerupuk sebelum dan sesudah digoreng, pengukuran panjang dan lebar irisan kerupuk menggunakan jangka sorong (Koesbandi, 1974). Persentase kemekaran dihitung dengan rumus :

Kemekaran $(\%)=\frac{L 1-L 2}{L 2} \times 100$

Keterangan :

$\mathrm{L} 1=$ Luas kerupuk mentah (panjang $\mathrm{x}$ lebar)

L2 = Luas kerupuk matang (panjang $\mathrm{x}$ lebar)

\section{Kerenyahan}

Kekerasan atau kerenyahan diukur dengan menggunakan metode penetrometer. Kerupuk direntangkan pada dasar alat penetrometer, kemudian ditusukkan jarum ke dalam kerupuk selama 1 detik. Nilai kerenyahan atau kekerasan dapat dilihat pada angka yang ditunjukkan oleh meter penunjuk. Semakin kecil nilai yang didapatkan, maka tingkat kerenyahannya semakin besar (Ranggana, 1986). 


\section{Uji Organoleptik}

Uji organoleptik dilakukan dengan menggunakan panelis agak terlatih sebanyak 20 orang. Uji ini menggunakan metode hedonik terhadap aspek warna, aroma, rasa dan tekstur kerupuk susu dengan skor penilaian mulai dari sangat tidak suka hingga sangat suka.

\section{Analisis Data}

Data hasil pengamatan akan dianalisis menggunakan ANOVA (analysisi of variance) untuk mengetahui ada tidaknya perbedaan perlakuan pada tingkat $\alpha=0,05$. Apabila terdapat beda nyata akan diuji lanjut dengan uji DMRT pada taraf $5 \%$ (Gomez, 2005).

\section{HASIL DAN PEMBAHASAN}

\section{Kadar Protein Kerupuk Susu}

Hasil Analisis Laboratorium terhadap Kadar Protein Kerupuk Susu pada berbagai variasi komposisi tepung dan jenis susu berkisar 6,32-11,05\%. Kadar protein masing-masing perlakuan dapat dilihat pada Tabel 1.

Hasil penelitian menunjukkan bahwa penggunaan berbagai variasi komposisi tepung dan jenis susu tidak berpengaruh nyata terhadap kadar protein kerupuk susu, kecuali pada perlakuan susu sapi, tepung campuran $100 \mathrm{~g}$ : beras $150 \mathrm{~g}$ : tapioka $250 \mathrm{~g}$ dengan kadar protein terendah dibandingkan perlakuan lainnya yaitu $6,32 \%$.

Tabel 1. Kadar Protein Kerupuk Susu pada Berbagai Variasi Komposisi Tepung dan Jenis Susu

\begin{tabular}{ccc}
\hline \multicolumn{2}{c}{ Perlakuan } & Kadar Protein (\%) \\
\cline { 1 - 2 } Komposisi Tepung (Terigu: beras : tapioka (g)) & Jenis Susu & \\
\hline $100: 150: 250$ & Kedelai & $10,82 \mathrm{a}$ \\
$100: 150: 250$ & Sapi & $6,32 \mathrm{~b}$ \\
$150: 250: 100$ & Kedelai & $11,05 \mathrm{a}$ \\
$150: 250: 100$ & Sapi & $9,97 \mathrm{a}$ \\
$250: 100: 150$ & Kedelai & $10,57 \mathrm{a}$ \\
$250: 100: 150$ & Sapi & $11,05 \mathrm{a}$
\end{tabular}

Ket : Angka yang diikuti dengan kode huruf yang berbeda menunjukkan adanya perbedaan yang nyata pada taraf signifikan $5 \%$. 
Hal ini dikarenakan kandungan protein kerupuk dipengaruhi oleh kandungan protein tepung yang digunakan. Dari ketiga jenis tepung yang digunakan kandungan protein tepung terigu lebih tinggi dibandingkan tepung beras dan tepung tapioka. Menurut Astawan (2000), kandungan protein tepung terigu $12-13 \%$, protein tepung tapioka $0,50 \%$ dan protein tepung beras $7,4 \%$ sedangkan protein susu sapi (SNI01-3141-1998) minimal 2,7 \% dan protein susu kedelai (SNI-01-3830-2006) minimal $2 \%$.

\section{Kerenyahan Kerupuk Susu}

Hasil pengujian terhadap tingkat kerenyahan kerupuk susu pada berbagai variasi komposisi tepung dan jenis susu bervariasi untuk setiap perlakuan yaitu berkisar 26,67-56,67. Tingkat kerenyahan masing-masing perlakuan dapat dilihat pada Tabel 2 .

Hasil pengujian kerenyahan kerupuk susu dengan berbagai variasi komposisi tepung dan jenis susu menunjukkan bahwa penggunaan susu sapi dan semakin banyak jumlah tepung tapioka yang digunakan kerupuk yang dihasilkan semakin renyah. Hal ini dikarenakan tingkat kerenyahan kerupuk dipengaruhi oleh kandungan amilopektin dari tepung yang digunakan. Menurut Tahir (1985), amilopektin merupakan salah satu komponen pati yang mempengaruhi kerenyahan kerupuk. Kandungan amilopektin lebih tinggi akan memberikan kecenderungan pengembangan kerupuk yang lebih besar dibanding dengan kandungan amilosa tinggi. Semakin mengembang kerupuk maka tekstur semakin renyah.

Tabel 2. Kerenyahan Kerupuk Susu pada Berbagai Variasi Komposisi Tepung dan Jenis Susu

\begin{tabular}{ccc}
\hline \multicolumn{2}{c}{ Perlakuan } & \\
\cline { 1 - 2 } Komposisi Tepung (Terigu: beras : tapioka $(\mathrm{g}))$ & Jenis Susu & Tingkat Kerenyahan \\
\hline $100: 150: 250$ & Kedelai & $41,67 \mathrm{a}$ \\
$100: 150: 250$ & Sapi & $56,67 \mathrm{~b}$ \\
$150: 250: 100$ & Kedelai & $26,67 \mathrm{e}$ \\
$150: 250: 100$ & Sapi & $30,00 \mathrm{~d}$ \\
$250: 100: 150$ & Kedelai & $26,67 \mathrm{e}$ \\
$250: 100: 150$ & Sapi & $38,33 \mathrm{c}$
\end{tabular}

Ket : Angka yang diikuti dengan kode huruf yang berbeda menunjukkan adanya perbedaan yang nyata pada taraf signifikan $5 \%$. 
Menurut Blitz (1987), tepung tapioka memilki kandungan amilopektin sebesar $55 \%$ dan amilosa $30 \%$, tepung terigu memilki kandungan amilopektin sebesar $25 \%$ dan amilosa sebesar $45 \%$ (Depkes RI, 1996) dan tepung beras memilki kandungan amilopektin 88 - 99 $\%$ dan amilosa sebesar $1-2 \%$.

\section{Kemekaran Kerupuk Susu}

Tingkat kemekaran kerupuk susu pada berbagai variasi komposisi tepung dan jenis susu bervariasi yaitu 41,3087,49\% (Tabel 3).

Hasil pengujiaan terhadap tingkat kemekaran kerupuk susu menunjukkan bahwa penggunaan jenis susu secara umum tidak memberikan pengaruh yang nyata. Sementara itu semakin banyak konsentrasi tepung tapioka yang digunakan dalam pembuatan kerupuk susu tingkat kemekaran kerupuk semakin tinggi, karena jumlah kandungan amilopektin tepung menentukan kemekaran kerupuk.

$$
\text { Menurut Tahir }
$$

amilopektin merupakan salah satu komponen pati yang mempengaruhi kerenyahan kerupuk. Kandungan amilopektin lebih tinggi akan memberikan kecenderungan pengembangan kerupuk yang lebih besar dibanding dengan kandungan amilosa tinggi, semakin mengembang kerupuk maka tekstur semakin renyah. Hal ini senada dengan hasil pengukuran tekstur, yang menyatakan semakin tinggi kadar tepung tapioka maka nilai tekstur semakin renyah.

Tabel 3. Kemekaran Kerupuk Susu pada Berbagai Variasi Komposisi Tepung dan Jenis Susu

\begin{tabular}{ccc}
\hline \multicolumn{2}{c}{ Perlakuan } & \\
\cline { 1 - 2 } Komposisi Tepung (Terigu: beras : tapioka $(\mathrm{g}))$ & Jenis Susu & Kemekaran (\%) \\
\hline $100: 150: 250$ & Kedelai & $87,49 \mathrm{a}$ \\
$100: 150: 250$ & Sapi & $85,17 \mathrm{a}$ \\
$150: 250: 100$ & Kedelai & $55,33 \mathrm{~b}$ \\
$150: 250: 100$ & Sapi & $41,30 \mathrm{c}$ \\
$250: 100: 150$ & Kedelai & $58,67 \mathrm{~b}$ \\
$250: 100: 150$ & Sapi & $58,08 \mathrm{~b}$
\end{tabular}

Ket : Angka yang diikuti dengan kode huruf yang berbeda menunjukkan adanya perbedaan yang nyata pada taraf signifikan $5 \%$. 
Menurut Astawan (2000), kandungan protein tepung terigu 12 $13 \%$, protein tepung tapioka $0,50 \%$ dan protein tepung beras $7,4 \%$ sedangkan protein susu sapi (SNI-01-3141-1998) minimal $2,7 \%$ dan protein susu kedelai (SNI-01-3830-1995) minimal $2 \%$.

\section{Uji Organoleptik Kerupuk Susu} dengan Berbagai Variasi Campuran Tepung dan Jenis Susu

\section{Warna Kerupuk Susu}

Nilai rerata organoleptik terhadap warna kerupuk susu dengan berbagai variasi komposisi tepung dan jenis susu dapat dilihat pada tabel 4 .

Hasil uji organoleptik pada Tabel 4 menjelaskan bahwa secara umum nilai rerata uji organoleptik terhadap warna kerupuk pada berbagai variasi komposisi tepung (tepung terigu, tepung beras dan tepung tapioka)dan jenis susu tidak berbeda nyata pada taraf $5 \%$ untuk semua perlakuan. Kerupuk susu yang dihasilkan dari penelitian ini secara keseluruhan berwarna putih kekuningan ,baik pada perlakuan susu kedelai maupun pada perlakuan susu sapi.

Hasil penilaian panelis terhadap warna kerupuk susu dengan variasi komposisi tepung (terigu, beras dan tapioka) dan jenis susu (susu kedelai dan susu sapi) dalam penelitian ini termasuk dalam skala $(3,15)$ agak suka hingga $(3,75)$ suka.

\section{Aroma}

Nilai rerata organoleptik terhadap aroma kerupuk susu dengan perlakuan berbagai variasi komposisi tepung dan jenis susu dapat dilihat pada tabel 5 .

Tabel 4. Tingkat Kesukaan Panelis terhadap Warna Kerupuk Susu pada Berbagai Variasi Komposisi Tepung dan Jenis Susu

\begin{tabular}{ccc}
\hline \multicolumn{2}{c}{ Perlakuan } & \\
\cline { 1 - 2 } Komposisi Tepung (Terigu: beras : tapioka $(\mathrm{g}))$ & Jenis Susu & warna \\
\hline $100: 150: 250$ & Kedelai & $3,2 \mathrm{~b}$ \\
$100: 150: 250$ & Sapi & $3,65 \mathrm{ab}$ \\
$150: 250: 100$ & Kedelai & $3,15 \mathrm{~b}$ \\
$150: 250: 100$ & Sapi & $3,25 \mathrm{~b}$ \\
$250: 100: 150$ & Kedelai & $3,55 \mathrm{ab}$ \\
$250: 100: 150$ & Sapi & $3,75 \mathrm{a}$
\end{tabular}

Ket : Angka yang diikuti dengan kode huruf yang berbeda menunjukkan adanya perbedaan yang nyata pada taraf signifikan $5 \%$ 
.Tabel 5.Tingkat Kesukaan Panelis Terhadap Aroma Kerupuk Susu pada Berbagai Variasi Komposisi Tepung dan Jenis Susu

\begin{tabular}{ccc}
\hline \multicolumn{2}{c}{ Perlakuan } & \\
\cline { 1 - 2 } Komposisi Tepung (Terigu: beras : tapioka $(\mathrm{g}))$ & Jenis Susu & warna \\
\hline $100: 150: 250$ & Kedelai & $3,45 \mathrm{~b}$ \\
$100: 150: 250$ & Sapi & $3,85 \mathrm{a}$ \\
$150: 250: 100$ & Kedelai & $3,65 \mathrm{ab}$ \\
$150: 250: 100$ & Sapi & $3,7 \mathrm{ab}$ \\
$250: 100: 150$ & Kedelai & $3,7 \mathrm{ab}$ \\
$250: 100: 150$ & Sapi & $3,75 \mathrm{a}$
\end{tabular}

Ket : Angka yang diikuti dengan kode huruf yang berbeda menunjukkan adanya perbedaan yang nyata pada taraf signifikan $5 \%$

Secara keseluruhan aroma kerupuk susu yang dihasilkan dalam penelitian ini beraroma khas kerupuk susu, yaitu aroma susu. Aroma susu pada kerupuk masih ada meskipun sudah mengalami proses pengolahan. Tabel 5 menjelaskan nilai rerata uji organoleptik terhadap aroma kerupuk susu variasi jenis susu (susu kedelai dan susu sapi) dan tepung (tepung terigu, tepung beras dan tepung tapioka) berbeda nyata pada taraf $5 \%$.

\section{Rasa}

Nilai rerata organoleptik terhadap Rasa kerupuk susu dengan perlakuan variasi komposisi tepung dan jenis susu dapat dilihat pada tabel 6. Rasa kerupuk susu yang dihasilkan dalam penelitian ini secara keseluruhan gurih. Hal ini dikarenakan adanya penambahan susu dalam proses pengolahan kerupuk susu.
Tabel 6 menjelaskan nilai rerata uji organoleptik terhadap rasa kerupuk susu variasi jenis susu (susu kedelai dan susu sapi) dan tepung (tepung terigu, tepung beras dan tepung tapioka) berbeda nyata pada taraf $5 \%$.

Jenis kerupuk susu yang menggunakan bahan susu sapi yang paling disukai adalah komposisi 100 gr terigu, 150 gr tepung beras, dan 250 gram tapioka. Sedangkan kerupuk susu yang menggunakan Susu Kedelai yang paling disukai adalah komposisi 250 gr terigu, 100 gr tepung beras, dan 150 gr tepung tapioka.

\section{Tekstur}

Nilai rerata organoleptik terhadap tekstur kerupuk susu dengan perlakuan variasi komposisi tepung dan jenis susu dapat dilihat pada tabel 7. Tabel 7 
menjelaskan nilai rerata uji organoleptik terhadap tekstur krupuk susu variasi jenis susu (susu kedelai dan susu sapi) dan tepung (tepung terigu, tepung beras dan tepung tapioka) berbeda nyata pada taraf 5 $\%$. Secara umum kerupuk susu perlakuan susu sapi lebih disukai daripada susu kedelai, karena kerupuk susu perlakuan susu sapi teksturnya agak renyah dibandingkan tekstur kerupuk susu perlakuan susu kedelai.

Hasil uji sensoris tekstur menunjukkan panelis lebih menyukai tekstur yang tidak terlalu renyah, apabila dilihat dari hasil uji tekstur secara objektif.

Tabel 6. Tingkat Kesukaan Panelis Terhadap Rasa Kerupuk Susu pada Berbagai Variasi Komposisi Tepung dan Jenis Susu

\begin{tabular}{ccc}
\hline \multicolumn{2}{c}{ Perlakuan } & \\
\cline { 1 - 2 } Komposisi Tepung (Terigu: beras : tapioka $(\mathrm{g}))$ & Jenis Susu & warna \\
\hline $100: 150: 250$ & Kedelai & $3,25 \mathrm{~b}$ \\
$100: 150: 250$ & Sapi & $3,85 \mathrm{a}$ \\
$150: 250: 100$ & Kedelai & $3,4 \mathrm{~b}$ \\
$150: 250: 100$ & Sapi & $3,6 \mathrm{ab}$ \\
$250: 100: 150$ & Kedelai & $3,95 \mathrm{a}$ \\
$250: 100: 150$ & Sapi & $3,65 \mathrm{ab}$
\end{tabular}

Ket : Angka yang diikuti dengan kode huruf yang berbeda menunjukkan adanya perbedaan yang nyata pada taraf signifikan $5 \%$.

Tabel 7. Tingkat Kesukaan Panelis Terhadap Tekstur Kerupuk Susu pada Berbagai Variasi Komposisi Tepung dan Jenis Susu

\begin{tabular}{ccc}
\hline \multicolumn{2}{c}{ Perlakuan } & \\
\cline { 1 - 2 } Komposisi Tepung (Terigu: beras : tapioka $(\mathrm{g}))$ & Jenis Susu & warna \\
\hline $100: 150: 250$ & Kedelai & $3,2 \mathrm{~b}$ \\
$100: 150: 250$ & Sapi & $3,5 \mathrm{ab}$ \\
$150: 250: 100$ & Kedelai & $3,25 \mathrm{~b}$ \\
$150: 250: 100$ & Sapi & $3,5 \mathrm{ab}$ \\
$250: 100: 150$ & Kedelai & $3,55 \mathrm{ab}$ \\
$250: 100: 150$ & Sapi & $3,85 \mathrm{a}$
\end{tabular}

Ket : Angka yang diikuti dengan kode huruf yang berbeda menunjukkan adanya perbedaan yang nyata pada taraf signifikan $5 \%$. 


\section{KESIMPULAN}

Komposisi tepung dan jenis susu mempengaruhi mutu kerupuk susu yang dihasilkan. Secara umum penggunan berbagai variasi komposisi tepung dan jenis susu tidak memberikan pengaruh yang signifikan terhadap kadar protein kerupuk susu tetapi berpengaruh terhadap tingkat kerenyahan, kemekaran, dan sifat organoleptik kerupuk susu yang dihasilkan.

\section{DAFTAR PUSTAKA}

Wiriano, H. 1984. Mekanisme Teknologi Pembuatan Kerupuk. Balai Pengembangan Makanan Phytokimia, Badan Penelitian dan Pengembangan Indusrti, Departemen Perindustrian, Jakarta.

SNI. 2714.1-2009. Syarat Mutu Kerupuk Udang. Badan Standarisasi Nasional Indonesia : Jakarta.

Anggoro, D. C. 2007. Sifat fungsional protein tepung daging sapi dengan metode pengeringan yang berbeda. Skripsi. Fakultas Peternakan. Institut Pertanian Bogor, Bogor.
Koesbandi S. 1974. Pengaruh Kadar Air terhadap 'Kerapuhan" (Cripness) Kerupuk Udang. [karya ilmiah]. Bogor: Institut Pertanian Bogor, Departemen Perikanan, Fakultas Kedokteran Hewan dan Peternakan, Universitas Brawijaya. Afiliasi Fakultas Perikanan, Institut Pertanian Bogor.

Koesbandi S. 1974. Pengaruh Kadar Air terhadap 'Kerapuhan" (Cripness) Kerupuk Udang. [karya ilmiah]. Bogor: Institut Pertanian Bogor, Departemen Perikanan, Fakultas Kedokteran Hewan dan Peternakan, Universitas Brawijaya. Afiliasi Fakultas Perikanan, Institut Pertanian Bogor.

Gomez, K. A., dan Gomez, A.A., 2005. Prosedur Statistik Untuk Penelitian Pertanian, edisi kedua, UI Press, Jakarta.

SNI.1998. Tepung Tapioka. Badan Standarisasi Nasional Indonesia : Jakarta.

SNI.01-3830-2006. Syarat Mutu Susu Kedelai. Badan Standarisasi Nasional Indonesia : Jakarta.

Tahir. S. 1985. Mempelajari pembuatan dan karakteristik kerupuk dari tepung sagu (Metroxylon Sagu R.). Skripsi Jurusan Teknologi Pertanian. Fakultas Pertanian. Universitas Hasanudin, Ujung Pandang. 